\title{
Analisis Identifikasi Pusat-Pusat Pertumbuhan dan Wilayah Pendukungnya dalam Pengembangan Wilayah Aceh
}

\author{
Nurlina \\ Prodi Ekonomi Pembangunan Fakultas Ekonomi Universitas Samudra \\ e-mail:nurlina@unsam.ac.id \\ Ayu Ridha Br. Ginting \\ Prodi Ekonomi Pembangunan Fakultas Ekonomi Universitas Samudra \\ e-mail:yu754727@gmail.com
}

\begin{abstract}
Abstrak
Penelitian ini bertujuan untuk mengidentifikasi kabupaten dan kota yang berpotensi sebagai pusat-pusat pertumbuhan ekonomi di Provinsi Aceh dan untuk menganalisis interaksi (tingkat keterkaitan) antara pusat pertumbuhan dan daerah sekitarnya kabupaten dan kota pendukung. Metode analisis skologram menunjukkan bahwa yang berada pada skala I adalah Aceh Tenggara, Banda Aceh dan Aceh Utara; skala II adalah Aceh besar dan Aceh Tamiang; skala III Bireun, Nagan Raya, Aceh Timur dan Aceh Barat; skala IV terdapat Aceh Tengah, Pidie, Aceh Selatan, Lhokseumawe, dan Aceh Singkil; serta, skala V terdapat Bener Meriah, Langsa, Simelue, Aceh Jaya, Pidie Jaya, Aceh Barat Daya, Gayo Lues, Subulussalam dan Sabang. Hasil interaksi wilayah kabupaten/kota untuk pusat pertumbuhan Kabupaten Aceh Tenggara didukung oleh Kabupaten Gayo Lues, Kota Subulussalam, Kabupaten Aceh Tengah, Kabupaten Aceh Singkil, Kabupaten Bener Meriah, dan Kabupaten Aceh Selatan; pusat pertumbuhan Kabupaten Aceh Utara didukung oleh Kota Lhokseumawe dan Kabupaten Bireun; pusat pertumbuhan Kota Banda Aceh didukung oleh Kota Sabang, Kabupaten Aceh Jaya, Kabupaten Aceh Barat, Kabupaten Nagan Raya, Kabupaten Aceh Barat Daya; pusat pertumbuhan Kabupaten Aceh Tamiang didukung Kota Langsa dan Kabupaten Aceh Timur; serta, pusat pertumbuhan Aceh Besar didukung Kabupaten Pidie dan Kabupaten Pidie Jaya.
\end{abstract}

Kata kunci: Pusat pertumbuhan, wilayah pendukung, pengembangan daerah.

\section{PENDAHULUAN}

Pembangunan merupakan suatu usaha menciptakan kesejahteraan masyarakat yang dilakukan secara berkesinambungan dan berencana untuk mendapat kondisi yang lebih baik. Proses pembangunan yang dilaksanakan pemerintah merupakan proses pembangunan yang menyeimbangkan antara pembangunan nasional dan pembangunan ekonomi daerah. Pembangunan nasional dilakukan untuk menunjang dan mendorong berkembangnya pembangunan daerah dan di lain pihak pembangunan daerah ditingkatkan untuk memperkokoh pembangunan nasional dan struktur perekonomian secara nasional yang mantap dan dinamis. Pembangunan ekonomi harus diikuti pembangunan sarana prasarana infrastruktur, transportasi, komunikasi dan kelembagaan sosial yang secara alami dapat meningkatkan daya tarik investasi. Implikasi dari upaya itu terhadap kegiatan ekonomi yang terjadi di masyarakat adalah bagaimana hasil produksi dari pusat-pusat pertumbuhan tersebut dapat dipakai untuk menunjang pelaksanaan kegiatan ekonomi yang berada didaerah sekitar pusat pengembangan. Sedang pada sisi lainnya adalah produksi hasil daerah pusat-pusat pertumbuhan dipakai untuk 
menunjang kegiatan ekonomi yang ada di pusat pertumbuhan. Pusat pertumbuhan ekonomi menjadi salah satu alternatif yang dapat digunakan untuk menggerakkan dan memacu pembangunan guna meningkatkan pendapatan masyarakat serta memudahkan pemerintah daerah mempercepat peningkatan kesejahteraan daerahnya. Pertumbuhan ekonomi jika diarahkan kepada daerah-daerah yang memiliki potensi dan fasilitas sarana dan prasarana wilayah akan dapat mempercepat terjadinya pertumbuhan ekonomi, karena secara tidak langsung kemajuan daerah akan membuat masyarakat mencari kehidupan yang lebih layak.

Provinsi Aceh merupakan salah satu provinsi yang berada di Pulau Sumatera. Provinsi Aceh terdiri dari 18 Kabupaten dan 5 Kota. Adanya pertumbuhan ekonomi adalah indikasi keberhasilan pembangunan ekonomi. Salah satu kebijakan yang dapat dilakukan pemerintah untuk mengembangkan wilayah adalah dengan menetapkan kota atau wilayah tertentu menjadi pusat pertumbuhan. Pusat pertumbuhan ekonomi merupakan salah satu cara untuk menggerakkan dan memacu pembangunan guna meningkatkan pendapatan masyarakat.

Perumusan masalah dalam penelitian ini adalah: (1)Apakah kabupaten dan kota berpeluang atau berpotensi sebagai pusatpusat pertumbuhan ekonomi di Provinsi Aceh?; serta, (2)Apakah terdapat interaksi (tingkat keterkaitan) antar pusat pertumbuhan dan daerah sekitarnya kabupaten dan kota pendukung? Tujuan penelitian ini adalah untuk mengidentifikasi kabupaten dan kota yang berpeluang atau berpotensi sebagai pusat-pusat pertumbuhan ekonomi di Provinsi Aceh; serta, untuk menganalisis interaksi (tingkat keterkaitan) antar pusat pertumbuhan dan daerah sekitarnya kabupaten dan kota pendukung.

\section{Pusat Pertumbuhan}

Teori Pertumbuhan Ekonomi Memiliki empat ciri (Tarigan, 2009), yaitu:

a. Adanya hubungan intern dari berbagai macam kegiatan. Keterkaitan antara satu sektor dengan sektor lain akan saling mendorong pertumbuhan karena hubungan yang dimiliki.

b. Ada efek penggandaan (multiplier effect). Keberadaan sektor-sektor yang saling terkait dan saling mendukung akan dapat menciptakan efek penggandaan. Permintaan akan menciptakan produksi baik sektor tersebut maupun sektor yang terkait akhirnya akan menjadi akumulasi modal. Unsur efek penggandaan sangat berperan dalam membuat kota mampu memacu pertumbuhan belakangnya.

c. Adanya konsentrasi geografis. Konsentrasi geografis dari berbagai sektor atau fasilitas, selain bisa menciptakan efisiensi di antara sektor-sektor yang saling membutuhkan, juga meningkatkan daya tarik dari kota tersebut.

d. Bersifat mendorong dari belakang. Terdapat hubungan yang harmonis antara Kota dan wilayah yang ada berada di belakangnya. Kota membutuhkan bahan baku dari wilayah belakangnya dan menyediakan berbagai kebutuhan wilayah belakangnya untuk dapat mengembangkan dirinya.

\section{Pusat Pertumbuhan Ekonomi Perroux}

Menurut Perroux (Adissasmita, 2013), berdasarkan fakta dasar perkembangan keruangan (spasial), pertumbuhan tidak terjadi di sembarang tempat dan juga tidak terjadi secara serentak. Pertumbuhan itu terjadi pada titik-titik ataupun kutub-kutub perkembangan, dengan kadar intensitas yang berubah-ubah, dan pertumbuhan itu menyebar sepanjang saluran-saluran yang beraneka ragam terhadap keseluruhan perekonomian.

\section{Pusat Pertumbuhan Ekonomi Richardson}

Richardson (2001:96) memberi definisi pusat pertumbuhan sebagai: "A growth pole was defined as a set of industries capable of generating dynamic growth in the industry (propulsive industry)". Dari definisi tersebut Richardson menjabarkan empat karakteristik utama sebuah pusat pertumbuhan, yaitu:

a. Adanya sekelompok kegiatan ekonomi terkonsentrasi pada suatu lokasi tertentu. 
b. Konsentrasi ekonomi tersebut mampu mendorong pertumbuhan ekonomi yang dinamis dalam perekonomian.

c. Terdapat keterkaitan input dan output yang kuat antara sesama kegiatan ekonomi pada pusat tersebut.

d. Dalam kelompok kegiatan ekonomi tersebut terdapat sebuah industri induk yang mendorong pengembangan kegiatan ekonomi pusat tersebut.

\section{Pusat Pertumbuhan Rondinelli dan Unwin}

Alonso (dalam Sirojuzilam \& Mahalli, 2010) menyatakan bahwa teori pusat pertumbuhan didasarkan pada keniscayaan bahwa pemerintah di negara berkembang dapat mempengaruhi pertumbuhan ekonomi dan kesejahteraan dengan melakukan investasi yang besar pada industri padat modal di pusat kota. Teori pusat pertumbuhan juga ditopang oleh kepercayaan bahwa kekuatan pasar bebas melengkapi kondisi terjadinya trickle down effect (dampak penetesan ke bawah) dan menciptakan spread effect (dampak penyebaran) pertumbuhan ekonomi dari perkotaan ke pedesaan.

\section{Pusat Sentral}

Teori tempat sentral merupakan suatu teori yang menyatakan bahwa daerah-daerah nodal itu mempunyai hirarki. Tidak semua daerah bersifat homogenitas, tetapi terdapat perbedaan baik dalam persebaran penduduk ataupun luas wilayahnya (Richardson, 2001).

Teori tempat sentral sangat relevan untuk digunakan didalam perencanaan wilayah. Hal ini dikarenakan teori tempat sentral menjelaskan tiga konsep dasar yang sangat penting peranannya dalam membangun wilayah: (a)ambang (threshold); (b)lingkup (range); dan, (c)hierarki (hierarchy).

\section{Model Gravitasi}

Sugiyanto (2010) menyatakan model gravitasi digunakan untuk melihat hubungan antar daerah yang memiliki potensi sumber daya alam, penduduk, pemusatan kegiatan, dan lainnya yang dianggap memiliki daya tarik. Dalam perencanaan wilayah, model ini sering dijadikan alat untuk melihat apakah lokasi berbagai fasilitas kepentingan umum telah berada pada tempat yang benar. Wilayah modal yang terbentuk melalui analisis gravitasi akan berperan sebagai sentral utama atau titik pertumbuhan bagi wilayah yang lebih kecil. Terjadinya wilayah ini karena dalamnya memiliki pengaruh akibat adanya jarak. Pengaruh ini semakin jauh dari pusat pengontrol, maka pada rentang radius tertentu kepadatan penduduk berkurang. Sedangkan yang terkuat akan membentuk polarisasi. Dengan demikian, pengertiannya adalah suatu wilayah yang bersifat heterogen dan didalam nya satu dengan yang lain berhubungan secara fungsional.

\section{Analisis Skalogram}

Metode skalogram adalah metode paling sederhana yang dapat digunakan untuk melakukan analisis fungsi wilayah, karena hanya menunjukkan daftar dari komponenkomponen pendukungnya (Riyadi, 2008). Komponen-komponen yang dibutuhkan biasanya meliputi:

a. Data pemukiman wilayah yang ditinjau.

b. Jumlah penduduk/populasi masing-masing pemukiman.

c. Data fungsi/fasilitas pelayanan yang terdapat pada setiap pemukiman.

Berdasarkan daftar itu, dapat dihitung rasio dari jumlah fungsi pelayanan yang ada dengan jumlah penduduk, baik dalam skala kabupaten maupun skala setiap wilayah atau kecamatan. Metode analisis skala Guttman merupakan suatu teknik skala, yang memiliki sedikit perbedaan dengan teknik-teknik skala lainnya. Perbedaan tersebut terletak pada persyaratan-persyaratan yang diajukan oleh Guttman dalam membentuk skalanya (Ardila, 2012). Persyaratan-persyaratan itu merupakan sifat-sifatnya, yaitu:

a. Variabel-variabel (pernyataan-pernyataan) dalam suatu set pernyataan harus bersifat homogen (undimensional) atau memiliki ketunggalan dimensi. Artinya, skala sebaiknya hanya mengukur satu dimensi saja dari variabel yang memiliki banyak dimensi. Misalnya, walaupun variabel nilai anak mempunyai dimensi ekonomi, 
dimensi psikologi, dan dimensi sosial, namun suatu skala nilai anak sebaiknya hanya mengukur salah satu dimensi saja.

b. Seperangkat variabel-variabel dalam suatu set pernyataan harus bersifat kumulatif, yang berarti pernyataan-pernyataan itu mempunyai bobot yang berbeda, dan apabila seorang responden menyetujui pernyataan yang lebih berat bobotnya, maka dia diharapkan akan menyetujui pernyataan-pernyataan yang lebih rendah atau ringan.

\section{Penelitian Sebelumnya}

Gore dan Fothergill (2007) melakukan penelitian dengan judul "Cities and Their Hinterlands: How Much do Governance Structures Really Matter". Penelitian ini bertujuan mengetahui pertumbuhan wilayah kota batu bara di Inggris dan serta struktur pemerintahan pendukungnya. Penelitian di lakukan pada tiga wilayah Kota Batu Bara di Inggris. Metode analisis data yang digunakan adalah metode deskriptif kualitatif. Hasil penelitian diketahui bahwa dari tiga wilayah kota batu bara dua kota diantaranya menjadi kota yang paling maju pertumbuhannya, yaitu kota baru bara Lothian, sementara dua kota lainnya adalah wilayah pendukungnya.

\section{METODE PENELITIAN}

Penelitian dilakukan di Provinsi Aceh, data yang digunakan adalah data banyaknya kabupaten dan kota, dan jumlah penduduk. Sumber data diperoleh dari Badan Pusat Statistik Aceh (BPS Aceh), jurnal, buku, yang berkaitan dengan penelitian ini.

\section{Metode Analisis Data}

Menganalisis data dalam penelitian ini menggunakan:

1. Analisis Skalogram.

Dalam analisis ini semua fasilitas umum yang dimiliki wilayah di data dan disusun dalam suatu tabel. Metode ini digunakan untuk menuliskan jumlah fasilitas yang dimiliki oleh setiap wilayah atau menuliskan ada/tidaknya fasilitas di suatu wilayah. Rumus mencari banyaknya kelas dari tiap-tiap kabupaten dan kota sebagai pusat pertumbuhan adalah sebagai berikut (Gulo, 2015):

$$
\mathrm{k}=1+3,3 \log \mathrm{n}
$$

dimana $k$ adalah banyaknya kelas, dan $n$ adalah banyaknya kabupaten dan kota.

Selanjutnya, untuk menentukan besar nya interval kelas, dengan cara:

$$
\frac{\mathrm{A}-\mathrm{B}}{\mathrm{k}}
$$

$\operatorname{dimana} A$ yaitu jumlah fasilitas bangunan tertinggi; $B$ yaitu jumlah fasilitas bangunan terendah; dan $k$ adalah banyaknya kelas.

\section{Analisis Gravitasi}

Model gravitasi dipergunakan dalam perencanaan wilayah. Model ini dapat membantu perencana wilayah untuk memperkirakan daya tarik suatu lokasi dibandingkan lokasi lain di sekitarnya. Rumus gravitasi (Gulo, 2015):

$$
P_{i} \cdot P_{j} A_{i j}=\frac{k}{d_{i j}^{b}}
$$

dimana $A_{i j}$ dimana besarnya interaksi wilayah $i$ dengan wilayah $j ; P_{i}$ adalah jumlah penduduk di wilayah $i$ dalam ribuan jiwa; $P$ adalah jumlah penduduk di wilayah $j$ dalam ribuan jiwa; $d_{i j}$ adalah jarak dari wilayah $i$ dengan wilayah $j$ (dalam $\mathrm{km}$ ); $k$ adalah sebuah bilangan konstanta berdasarkan pengalaman; dan, $b$ adalah peringkat dari $d_{i j}$ yang sering digunakan $(b=2)$.

3. Indeks Sentral

$$
C=\frac{t}{T}
$$

dimana $C$ adalah Indeks Sentral; $t$ adalah bobot atribut suatu fasilitas; dan, $T$ adalah jumlah total atribut fasilitas.

\section{HASIL ANALISIS \\ Hasil Penelitian}

Luas Provinsi Aceh adalah sebesar 5.677.081 ha, dengan hutan sebagai lahan terluas yang mencapai 2.270 .080 ha, diikuti lahan perkebunan rakyat seluas 700.350 ha. Sedangkan lahan industri memiliki luas terkecil, yaitu 2.096 ha. Kemudian jumlah 
penduduk di Provinsi Aceh pada tahun 2017 adalah sebesar 5.096.248 jiwa yang tersebar di setiap daerah (18 Kabupaten dan 5 Kota).

\section{Fasilitas Pendidikan}

Tingkat pendidikan suatu masyarakat ditentukan dengan ketersediaan berbagai fasilitas pendidikan yang dapat menunjang kegiatan belajar mengajar di daerah tersebut. Total sekolah Taman Kanak-Kanak di Provinsi Aceh berjumlah 2,212 unit yang tersebar di Kabupaten/Kota. Penyebarannya pun hampir merata di setiap Kabupaten/Kota yang disesuaikan dengan besarnya jumlah penduduk dan luasnya wilayah. Kabupaten Aceh Utara merupakan Kabupaten yang memiliki paling banyak jumlah TK, yaitu sebanyak 241 unit.

Begitupun halnya dengan Sekolah Dasar/Sederajat yang tersebar di Kabupaten/ Kota di Provinsi Aceh pada tahun 2017 sebanyak 4.068 unit. Kabupaten Aceh Utara memiliki SD/Sederajat terbanyak sebanyak 409 unit, disusul dengan Kecamatan Pidie sebanyak 337 unit serta Kabupaten/Kota yang memiliki SD/Sederajat, paling sedikit adalah Kota Sabang.

Untuk SMP/Sederajat yang ada di Provinsi Aceh sebanyak 1.471 unit dengan jumlah terbanyak berada di Aceh Utara sebanyak 179 unit dan jumlah paling sedikit Kota Sabang sebanyak 11 unit. Di Provinsi Aceh, jumlah SMA/Sederajat sebanyak 977 unit. Kabupaten Aceh Utara merupakan Kabupaten dengan jumlah SMA/Sederajat terbanyak diantara kecamatan lainnya yaitu sebesar 101 unit, dan Kabupaten Gayo Lues merupakan Kabupaten yang memiliki jumlah SMA paling sedikit sebanyak 20 unit.

\section{Fasilitas Kesehatan}

Fasilitas Kesehatan yang ada di Provinsi Aceh terdiri dari Puskesmas, Rumah Sakit, Puskesmas Pembantu dan Polindes. Jumlah fasilitas kesehatan di Provinsi Aceh pada tahun 2017 berupa Puskesmas yang telah tersebar di Kabupaten/Kota dengan jumlah 340 unit, dengan jumlah terbanyak berada di Kabupaten Aceh Utara sebanyak 31 unit dan jumlah terkecil berada di Kota Langsa dan
Kota Subulussalam dengan masing-masing sebanyak 5 unit. Fasilitas kesehatan rumah sakit yang telah tersebar di Kabupaten/Kota di Provinsi Aceh dengan jumlah paling sedikit masing-masing 1 dan jumlah paling banyak sebesar 15 unit di Kota Banda Aceh. Sedangkan jumlah fasilitas kesehatan Puskesmas Pembantu dan Polindes yang ada di Provinsi Aceh sebanyak 929 unit dan 2.322 unit yang tersebar diseluruh Kabupaten/Kota.

\section{Fasilitas Peribadatan}

Pembangunan di bidang kehidupan beragama dan kepercayaan kepada Tuhan Yang Maha Esa diarahkan mampu meningkatkan kualitas umat beragama sehingga tercipta suasana kerukunan hidup yang erat.

Fasilitas peribadatan di Provinsi Aceh yang paling dominan adalah Mesjid. Hal ini dikarenakan di Provinsi Aceh Penduduknya mayoritas beragama Islam, sementara tempat peribadatan lain seperti gereja, pura dan vihara jumlahnya terbatas, terkecuali di Kabupaten Aceh Tenggara. Hal ini karena di kabupaten ini banyak penduduknya yang beragama Kristen. Sementara untuk penduduk beragama Hindu dan Budha jumlahnya sedikit dan menggunakan tempat peribadatan berupa vihara dan pura. Di Provinsi Aceh pada tahun 2017 terdapat 3.939 unit masjid, 42 unit gereja, 0 unit pura dan 17 unit vihara.

\section{Analisis Skalogram dan Indeks Sentralitas}

Metode analisis ini digunakan untuk mengetahui pusat pertumbuhan ekonomi di wilayah Kabupaten/Kota yang ada di Provinsi Aceh dengan melihat ketersediaan fasilitas umum dalam suatu wilayah. Selanjutnya, analisis skalogram ini dikembangkan untuk menentukan indeks sentralitas terbobot. Penentuan hirarki pusat pertumbuhan dengan indeks sentralitas ini tidak hanya berdasarkan jumlah fungsi atau fasilitas pelayanan yang ada pada suatu wilayah, tetapi juga berdasarkan frekuensi keberadaan fungsi atau fasilitas tersebut pada wilayah yang ditinjau.

Analisis Skalogram dan Indeks Sentralitas ini dapat menunjukkan bahwa wilayah yang merupakan hirarki tinggi adalah 
Kabupaten/Kota yang memiliki jumlah jenis fungsi/fasilitas yang nilai indeks sentralitas dengan kategori tinggi ke atas atau Kabupaten/Kota tersebut dapat dikategorikan sebagai pusat pertumbuhan ekonomi, sedangkan wilayah-wilayah yang merupakan hirarki paling rendah ditentukan oleh semakin sedikitnya jumlah fungsi /fasilitas dan nilai indeks sentralitas yang paling rendah pula. Dalam penelitian ini dibagi menjadi 5 kelas dengan pembagian sebagai berikut:

a. Hirarki I dengan ketersedian jumlah fungsi/fasilitas dan nilai indeks sentralitas sangat tinggi.

b. Hirarki II dengan ketersediaan jumlah fungsi/fasilitas dan nilai indeks sentralitas tinggi.

c. Hirarki III dengan ketersediaan jumlah fungsi/fasilitas dan nilai indeks sentralitas sedang.

d. Hirarki IV dengan ketersediaan jumlah fungsi/fasilitas dan nilai indeks sentralitas rendah.

e. Hirarki V dengan ketersediaan jumlah fungsi/Fasilitas dan nilai indeks sentralitas sangat rendah.

Beberapa data yang yang digunakan dalam analisis skalogram berjumlah 12 jenis fungsi/fasilitas. Jenis-jenis fasilitas tersebut diantaranya meliputi fasilitas pendidikan, fasilitas kesehatan dan fasilitas peribadatan, fasilitas ekonomi dan pemerintahan. Secara keseluruhan, fasilitas yang ada di data ada sebanyak 14 jenis fasilitas yang akan digunakan untuk menggambarkan hirarki setiap Kabupaten/Kota. Fasilitas tersebut terdiri dari fasilitas pendidikan seperti Taman Kanak-kanak, Sekolah Dasar, Sekolah Menengah Pertama, Sekolah Menengah Atas, Taman Pendidikan Alquran; fasilitas kesehatan seperti Rumah Sakit, Puskesmas, Pustu, Posyandu dan Klinik; fasilitas umum seperti jalan, jembatan, dan irigasi.

Hasil analisis skalogram yakni analisis yang menelaah keberadaan fasilitasnya. Kabupaten/Kota yang ada di Provinsi Aceh dikategorikan ke dalam kelompok-kelompok. Dari 14 jenis fasilitas yang di data, jumlah jenis fasilitas tertinggi yang ada di dalam satu
Kabupaten/Kota adalah sebanyak 14 jenis fasilitas, sementara yang terendah adalah 9 jenis fasilitas. Dengan memperhitungkan selisih antara jumlah fasilitas tertinggi dan terendah, maka Kabupaten/Kota yang ada di Provinsi Aceh dibagi atas 5 kelompok.

Hirarki I adalah kelompok Kabupaten/ Kota dengan tingkat keberadaan fasilitas yang tertinggi, yakni Kabupaten yang memiliki 13 sampai 14 jenis fasilitas. Kabupaten/Kota yang berada di Hirarki I yaitu Aceh Singkil, Bireuen, Aceh Utara, Aceh Barat Daya, Nagan Raya, Banda Aceh, Sabang, Langsa dan Lhokseumawe. Jenis fasilitas yang membedakan dengan kelompok lainnya yaitu keberadaan fasilitas tempat peribadatan dan fasilitas ekonomi yaitu perusahaan.

Kabupaten/Kota yang juga memiliki keberadaan fasilitas yang tinggi adalah Kabupaten/Kota yang berada di Hirarki II, yaitu Aceh Selatan, Aceh Tengah, Aceh Barat dan Aceh Besar. Jenis fasilitas yang membedakan Hirarki II adalah tempat ibadah, fasilitas ekonomi dan pemerintahan.

Hirarki III yaitu dengan ketersediaan fasilitas yang sedang, yakni termasuk Kabupaten/Kota Aceh, Tamiang, Aceh Jaya, dan Pidie Jaya. Pada Hirarki IV dan Hirarki V menandakan Kabupaten/Kota yang memiliki fasilitas yang rendah. Kabupaten/Kota yang termasuk dalam Hirarki IV adalah Aceh Tenggara, Aceh Timur, Gayo Lues, Bener Meriah dan Subulussalam. Pada Hirarki V adalah Kabupaten/Kota Simeuleu dan Pidie. Fasilitas yang membedakannya yaitu fasilitas peribadatan seperti mesjid, gereja, pura, dan virhara, kemudian fasilitas pemerintahan dan ekonomi serta fasilitas pendidikan yang mana terdapat banyak sekolah-sekolah swasta di beberapa Kabupaten/Kota.

Pada hasil analisis skalogram dapat dilihat bahwa kecamatan yang memiliki jumlah penduduk besar, namun tingkat keberagaman fasilitas yang ada pada Kabupaten/Kota tersebut rendah seperti yang ada di Kabupaten Pidie. Selain itu, ada juga Kabupaten/Kota yang memiliki jumlah penduduk yang kecil namun keberagaman fasilitas yang tinggi seperti Sabang dan Singkil. Meski demikian, untuk menentukan 
Kabupaten/Kota sebagai pusat pertumbuhan tidaklah hanya cukup melihat keberagaman fasilitas saja, tetapi juga mempertimbangkan frekuensi setiap jenis fasilitas tersebut.

Berdasarkan hasil analisis Indeks Sentralitas, Kabupaten Aceh Tenggara merupakan Kabupaten/Kota yang memiliki nilai indeks sentralitas yang sangat tinggi yakni 104,2. Nilai tersebut merupakan nilai tertinggi di antara $23 \mathrm{Kabupaten/Kota} \mathrm{lainnya}$ yang ada di Provinsi Aceh, sehingga Kabupaten Aceh Tenggara berada pada Hirarki I. Selain Kabupaten Aceh Tenggara, Kabupaten/Kota yang memiliki nilai indeks sentralitas yang sangat tinggi, yaitu Kota Banda Aceh dan Kabupaten Aceh Utara dengan masing-masing nilai indeks sebesar 98,89 dan 94,51.

Kabupaten Aceh Tenggara sebagai pusat pertumbuhan erat kaittannya ditetapkan karena Kabupaten ini memiliki pusat pertambangan dan pusat pariwisata yang terkenal. Kabupaten Aceh Tenggara memiliki jumlah penduduk yang cukup banyak dan memerlukan kebutuhan fasilitas sosial, sehingga di Kabupaten ini banyak dibangun fasilitas sosial, yaitu sarana peribadatan. Hal ini terlihat dari banyaknya jumlah fasilitas sosial, yaitu sarana peribadatan gereja sebanyak 24 unit. Fasilitas ini sangat banyak dibandingkan fasilitas sarana peribadatan gereja di Kabupaten/Kota lain. Oleh karena itu, kabupaten ini berfungsi sebagai kawasan pusat pertumbuhan dalam rangka memberikan pelayanan kepada masyarakat dan sebagai pengembangan wilayah lainnya di Provinsi Aceh.

Selanjutnya Kabupaten/Kota yang memiliki nilai indeks sentralitas yang tinggi yaitu Aceh Utara.Kabupaten ini memiliki jumlah penduduk yang sangat tinggi dibandingkan Kabupaten/Kota lainnya, yaitu sebesar 593.492 jiwa pada tahun 2017. Jumlah penduduk yang sangat besar ini mengakibatkan kebutuhan masyarakat akan ketersediaan fasilitas sosial juga semakin tinggi, sehingga di kecamatan ini banyak dibangun fasilitas sosial seperti sarana pendidikan, kesehatan, peribadatan, perusahaan dan pemerintahan. Hal ini terlihat dari banyaknya jumlah fasilitas sosial sebanyak 1.440 unit; terbanyak diantara fasilitas sosial lainnya. Oleh karena itu, kabupaten ini dapat berfungsi sebagai kawan pusat pertumbuhan yang penting dalam rangka memberikan pelayanan kepada masyarakat dan juga pengembangan wilayah di Kabupaten lainnya di Provinsi Aceh.

Kota Banda Aceh sebagai pusat pertumbuhan erat kaitannya dengan posisinya sebagai ibukota Provinsi Aceh dan sekaligus sebagai pusat pemerintahan. Hasilnya, kecamatan ini banyak berkembang usaha atau aktivitas perekonomian masyarakat, baik itu usaha perdagangan dan jasa, industri kecil dan juga banyaknya pembangunan berbagai fasilitas-fasilitas baik ekonomi, sosial dan pemerintahan. Selain itu, industri-industri berkembang di wilayah ini yang banyak menyerap tenaga kerja baik dari dalam maupun luar wilayah. Kota Banda Aceh memiliki fasilitas transportasi yang lengkap seperti bandara dan pelabuhan. Kota ini juga memiliki fasilitas pendidikan yang cukup lengkap dari jenjang TK sampai dengan tingkat universitas.

Selanjutnya, Kabupaten/Kota yang memiliki indeks sentralitas yang tinggi adalah Kabupaten Aceh Tamiang dengan nilai sebesar 74,43 sehingga kabupaten ini dikategorikan sebagai pusat pertumbuhan ekonomi yang berada pada Hirarki II. Selain Kabupaten Aceh Tamiang, Kabupaten/Kota yang berada pada Hirarki II adalah Kabupaten Aceh Besar dengan nilai indeks sentralitas 83,75 . Di kabupaten ini potensi yang banyak menyumbang untuk PDRB terdapat pada bidang pertanian.

Berdasarkan hasil analisis skalogram dan indeks sentralitas atas banyaknya ketersediaan fasilitas sosial, ekonomi dan pemerintahan, bisa diketahui bahwa hubungan antara fasilitas yang tersedia dengan fungsi daerah sebagai pusat pertumbuhan adalah semakin tinggi nilai indeks sentralitas yang dimiliki dan akan menempatkan wilayah tersebut memiliki fungsi yang lebih besar dibanding wilayah lainnya.

Kabupaten/Kota yang memiliki ketersediaan fasilitas yang lengkap menandakan 
bahwa Kabupaten/Kota tersebut memiliki kemampuan lebih baik dalam memberikan pelayanan kepada masyarakat. Selanjutnya, karena kondisi ini Kabupaten/Kota tersebut mampu berperan sebagai pusat pertumbuhan pada kawasan itu. Pengembangan wilayah melalui konsep pusat pertumbuhan ini tidak berarti hanya pengembangan yang terjadi pada Hirarki I saja, namun harus dilakukan dengan secara berjenjang sehingga akan mempercepat perkembangan kegiatan ekonomi di seluruh wilayah, khususnya pada wilayah yang lemah pertumbuhan dan perkembangannya. Hirarki atau kelompok pusat pertumbuhan pada Provinsi Aceh adalah sebagai berikut:

a. Hirarki I adalah Kabupaten Aceh Tenggara, Kabupaten Aceh Utara dan Kota Banda Aceh.

b. Hirarki II adalah Kabupaten Aceh Tamiang dan Kabupaten Aceh Besar.

c. Hirarki III adalah Kabupaten Aceh Timur, Kabupaten Bireuen dan Kabupaten Nagan Raya.

d. Hirarki IV adalah Kabupaten Aceh Singkil, Kabupaten Aceh Selatan, Kabupaten Aceh Tengah, Kabupaten Pidie dan Kota Lhokseumawe.

e. Hirarki V adalah Kabupaten Siemeulu, Kabupaten Aceh Barat Daya, Kabupaten Gayo Lues, Kabupaten Aceh Jaya, Kabupaten Pidie Jaya, Kota Sabang, Kota Langsa dan Kota Subulussalam

\section{Analisis Gravitasi}

Analisis gravitasi dalam penelitian ini digunakan untuk menilai kekuatan hubungan (kedekatan) antara dua daerah dimana daerah dianggap sebagai suatu massa yang memiliki daya tarik-menarik, sehingga akan muncul hubungan saling mempengaruhi antara kedua daerah tersebut. Dalam ekonomi regional, hubungan antara daerah bisa diidentifikasikan sebagai interaksi ekonomi antara pusat pertumbuhan dengan daerah sekitarnya. Dari 23 Kabupaten/Kota dapat diidentifikasikan 5 kabupaten/kota di Provinsi Aceh yang memiliki hirarki tinggi sebagai pusat pertumbuhan. Beberapa daerah pendukung (hinterland) dari setiap pusat pertumbuhan secara individu yang dapat dikelaskan sebagai berikut:

a) Pusat pertumbuhan Kabupaten Aceh Tenggara memiliki daerah keliling yaitu Kabupaten Aceh Singkil, Kabupaten Aceh Selatan, Kabupaten Gayo Lues, Kabupaten Aceh Tengah, Kabupaten Bener Meriah dan Kota Subulussalam.

b) Pusat pertumbuhan Kabupaten Aceh Utara memiliki daerah keliling yaitu Kabupaten Bireuen dan Kota Lhokseumawe.

c) Pusat Pertumbuhan Kota Banda Aceh memiliki daerah keliling yaitu Kabupaten Aceh Barat, Kabupaten Aceh Barat Daya, Kabupaten Aceh Jaya, Kota Sabang dan Kabupaten Nagan Raya.

d) Pusat pertumbuhan Kabupaten Aceh Tamiang memiliki daerah keliling yaitu Langsa dan Kabupaten Aceh Timur.

e) Pusat pertumbuhan Kabupaten Aceh Besar memiliki daerah keliling yaitu Kabupaten Pidie dan Pidie Jaya.

\section{Pembuktian Hipotesis}

Berdasarkan hasil perhitungn metode interaksi atau gravitasi menggunakan variabel jumlah penduduk dan jarak antara Kabupaten/ Kota, maka diketahui interaksi dari masingmasing Kabupaten/Kota sebagai pusat pertumbuhan dan Kabupaten/Kota sekitarnya dan dapat terlihat pada Tabel 1.

Dari hasil perhitungan angka interaksi pusat pertumbuhan terhadap masing-masing Kabupaten/Kota, maka diperoleh nilai yang berbeda. Berdasarkan Tabel 1, Kabupaten Aceh Tenggara memiliki interaksi paling erat dengan Kabupaten Gayo Lues sebagai daerah sekitarnya, sesuai besarnya angka interaksi kedua Kabupaten ini. Juga pusat pertumbuhan Kabupaten Aceh Utara memiliki interaksi paling erat dengan Kota Lhokseumawe sebagai daerah sekitarnya. Kota Banda Aceh memiliki interaksi paling erat dengan Kota Sabang sebagai daerahnya. Pusat pertumbuhan Kabupaten Aceh Tamiang memiliki interaksi paling erat dengan Kota Langsa sebagai daerah sekitarnya, dan Kabupaten Aceh Besar memiliki interaksi paling erat dengan Kabupaten Pidie sebagai daerah sekitarnya. 
Tabel 1. Hasil Interaksi Kabupaten/Kota Pusat Pertumbuhan Tahun 2017

\begin{tabular}{|c|c|c|c|}
\hline No & $\begin{array}{c}\text { Kabupaten/Kota } \\
\text { Pusat Pertumbuhan }\end{array}$ & Kecamatan Hinterland & Nilai Interaksi \\
\hline \multirow{6}{*}{1.} & \multirow{6}{*}{ Aceh Tenggara } & Gayo Lues & 2.181 .009 \\
\hline & & Subulussalam & 340.967 \\
\hline & & Aceh Tengah & 730.778 \\
\hline & & Aceh Singkil & 369.891 \\
\hline & & Bener Meriah & 410.397 \\
\hline & & Aceh Selatan & 392.707 \\
\hline \multirow{2}{*}{2.} & \multirow{2}{*}{ Aceh Utara } & Lhokseumawe & 81.073 .689 \\
\hline & & Bireuen & 33.239 .373 \\
\hline \multirow{5}{*}{3.} & \multirow{5}{*}{ Banda Aceh } & Sabang & 1.339 .122 \\
\hline & & Aceh Jaya & 1.008 .751 \\
\hline & & Aceh Barat & 890.665 \\
\hline & & Nagan Raya & 489.646 \\
\hline & & Aceh Barat Daya & 285.510 \\
\hline \multirow{2}{*}{4.} & \multirow{2}{*}{ Aceh Tamiang } & Langsa & 41.317 .235 \\
\hline & & Aceh Timur & 9.975 .949 \\
\hline \multirow{2}{*}{5.} & \multirow{2}{*}{ Aceh Besar } & Pidie & 9.539 .399 \\
\hline & & Pidie Jaya & 2.607 .795 \\
\hline
\end{tabular}

Sumber: Data sekunder (diolah), Tahun 2017.

Dari perhitungan interaksi tersebut, hanya menggambarkan tingkat interaksi dari satu Kabupaten/Kota sebagai pusat pertumbuhan dengan Kabupaten/Kota sebagai daerah kelilingnya. Oleh karena itu harus dianalisis total aksebilitas yang terjadi antara satu Kabupaten/Kota dengan seluruh Kabupaten/Kota yang ada, sehingga dapat diketahui kecamatan mana sebagai pusat pertumbuhan yang memiliki daya tarik lebih tinggi dari kecamatan lainnya.

Hipotesis pertama yang menyatakan terdapat beberapa wilayah kabupaten dan kota di Provinsi Aceh menjadi pusat pertumbuhan dapat diterima, yaitu wilayah Kabupaten Aceh Tenggara, Aceh Utara, Banda Aceh, Aceh Tamiang dan Aceh Besar. Selanjutnya, hipotesis kedua yang menyatakan terdapat keterkaitan antara daerah kabupaten dan kota yang menjadi pusat pertumbuhan dengan daerah kabupaten dan kota yang menjadi pendukungnya adalah diterima, yaitu Aceh Tenggara dengan wilayah pendukung Gayo Lues, Subulusalam, Aceh Tengah, Aceh Singkil, Bener Meriah dan Aceh Selatan. Kemudian Aceh Utara dengan wilayah pendukungnya Lhokseumawe dan Bireuen.
Banda Aceh dengan wilayah pendukungnya Sabang, Aceh Jaya, Aceh Barat, Nagan Raya dan Aceh Barat Daya. Aceh Tamiang dengan wilayah pendukungnya Langsa dan Aceh Timur. Terakhir, Aceh Besar dengan wilayah pendukungnya Pidie dan Pidie Jaya.

\section{KESIMPULAN}

Berdasarkan hasil-hasil penelitian dan pembahasan maka dapat ditarik beberapa kesimpulan berikut.

Pertama, berdasarkan hasil penelitian diketahui bahwa fasilitas pendidikan di Provinsi Aceh untuk taman kanak-kanak sebanyak 2,212 unit, dan Kabupaten Aceh Utara adalah yang terbanyak yaitu 241 unit. Kemudian sekolah dasar sebanyak 4.068 unit dan terbanyak di Kabupaten Aceh Utara sebanyak 409 unit. Sekolah Menengah Pertama sebanyak 1.471 unit, dengan jumlah terbanyak berada di Aceh Utara sebanyak 179 unit. Selanjutnya, Sekolah Menengah Atas sebanyak 977 unit, terbanyak di Kabupaten Aceh Utara sebanyak 101 unit. Kemudian fasilitas kesehatan untuk Puskesmas sebanyak 340 unit, Rumah Sakit sebanyak 66 unit, Pustu sebanyak 929 unit dan Polindes 
sebanyak 2.322 unit. Fasilitas peribadatan untuk masjid sebanyak 3.939 unit, gereja sebanyak 42 unit pura tidak ada dan vihara sebanyak 17 unit.

Kedua, hasil analisis skalogram dan sentralisasi diketahui bahwa yang berada pada skala I adalah Aceh Tenggara, Banda Aceh dan Aceh Utara. Pada skala II adalah Aceh besar dan Aceh Tamiang. Pada skala III adalah Bireun, Nagan Raya, Aceh Timur dan Aceh Barat. Pada skala IV terdapat Aceh Tengah, Pidie, Aceh Selatan, Lhokseumawe, dan Aceh Singkil. Pada skala V terdapat Bener Meriah, Langsa, Simelue, Aceh Jaya, Pidie Jaya, Aceh Barat Daya, Gayo Lues, Subulussalam dan Sabang.

Terakhir, berkenaan dengan hasil interaksi wilayah kabupaten/kota, untuk pusat pertumbuhan Kabupaten Aceh Tenggara didukung oleh Kabupaten Gayo Lues, Kota Subulussalam, Kabupaten Aceh Tengah, Kabupaten Aceh Singkil, Kabupaten Bener Meriah, dan Kabupaten Aceh Selatan. Pusat pertumbuhan Kabupaten Aceh Utara didukung oleh Kota Lhokseumawe dan Kabupaten Bireun. Pusat pertumbuhan Kota Banda Aceh didukung oleh Kota Sabang, Kabupaten Aceh Jaya, Kabupaten Aceh Barat, Kabupaten Nagan Raya, Kabupaten Aceh Barat Daya. Pusat pertumbuhan Kabupaten Aceh Tamiang didukung Kota Langsa dan Kabupaten Aceh Timur. Pusat pertumbuhan Aceh Besar didukung Kabupaten Pidie dan Kabupaten Pidie Jaya.

Berdasarkan beberapa kesimpulan itu, dikemukakan tiga rekomendasi. Pertama, bagi pemerintah propinsi dapat menambahkan fasilitas pendidikan daerah yang masih membutuhkan seperti di Kabupaten Gayo Lues; dan fasilitas kesehatan seperti Rumah Sakit, dimana masih banyak Kabupaten dan Kota yang hanya memiliki satu rumah sakit.

Kedua, pemerintah propinsi perlu menambah fasilitas bagi daerah Hinterland atau wilayah pendukung sehingga tidak ada kesenjangan dengan wilayah kabupaten/ kota sebagai pusat pertumbuhan. Ketiga, bagi peneliti selanjutnya bisa menambahkan penelitian tentang interaksi ekonomi.

\section{DAFTAR PUSTAKA}

Adisasmita, R. 2013. Teori-Teori Pembangunan Ekonomi. Yogyakarta: Graha Ilmu.

Ardila. 2012. Analisis Pengembangan Pusat Pertumbuhan Ekonomi di Kabupaten Banjarnegara. Jurnal Ekonomi. Vol. 6, No. 8, hal. 86-94.

Ermawati. 2010. Analisis Pusat Pertumbuhan Ekonomi pada Tingkat Kecamatan di Kabupaten Karanganyar Provinsi Jawa Tengah. Skripsi. Surakarta: Fakultas Ekonomi Universitas Sebelas Maret.

Gore, T. dan Fothergill, S. 2007. Cities and Their Hinterlands: How Much do Governance Structures Really Matter. Journal Compilation. Vol. 1, No.2, hal. 55-68.

Richardson, H.W. 2001. Dasar-Dasar Ilmu

Regional. Alihbahasa: Paul Sitohang. Jakarta: Lembaga Penerbit Fakultas Ekonomi Universitas Indonesia.

Riyadi. 2008. Perencanaan Pembangunan Daerah Strategi Menggali Potensi dalam Mewujudkan Otonomi Daerah. Jakarta: PT. Gramedia Pustaka Utama.

Sagala, S. 2009. Hasil Analisis Pusat Pertumbuhan di Kabupaten Ogan Hilir. Jakarta.

Sugiyanto. 2010. Penelitian Pengembangan Pusat-Pusat Pertumbuhan Ekonomi di Kabupaten Lamandau. Surabaya: Fakultas Ekonomi Universitas Dr. Soetomo.

Sugiyono. 2011. Metode Penelitian Kuantitatif, Kualitatif dan R\&D. Bandung: Alfabeta.

Syahrizal. 2008. Ekonomi Regional: Teori dan Aplikasi. Jakarta: Niaga Swadaya

Tarigan, R. 2009. Perencanaan Pembangunan Wilayah. Jakarta: Bumi Aksara.

Wibowo, R. 2007. Konsep, Teori dan Landasan Analisis Wilayah. Malang: Bayumedia Publishing. 